\title{
The Research on People's Enterprise Skills in Serbia ${ }^{5}$
}

Article history:

Received 05 September 2012

Sent for revision 09 January 2013

Received in revised form 23 January 2013

Accepted 15 April 2013

Available online 15 April 2013

Abstract: In this paper authors analyse the attitudes and the perceptions of potential entrepreneurs from the Mačva district in Serbia. The research based on GEM methodology shows that entrepreneurs have only modest enterprise skills. Such results were expected, due to the fact that entrepreneurship as a concept in this region is only in the early stages. Potential entrepreneurs in Mačva need additional training. The results also show that in average they graduated from secondary school and that they differ in age. It has been stated that potential entrepreneurs may play certain roles in their companies, but however, they are not ready to take the leading position yet.

Keywords: Perception, Entrepreneurs, Enterprise, GEM

Apstrakt:Istraživanjem su analizirani stavovi i percepcija potencijalnih preduzetnika iz Mačvanskog okruga. Nalazi ukazuju na skromne preduzetničke sposobnosti, što je razumljivo, jer je preduzetništvo kao koncept na ovim prostorima tek u početnim fazama. Potencijalnim preduzetnicima potrebna je dodatna obuka. Istraživanje ukazuje da su potencijalni preduzetnici različitog starosnog doba i srednje stručne spreme. Zaključeno je da u ovom trenutku srpski preduzetnik sa svojim stavovima, može da ima ulogu u biznis timu, ali da nije spreman da preuzme vodeću ulogu.

Ključne reči: Percepcija, Preduzetnici, Preduzeće

\footnotetext{
${ }_{1}^{1}$ Prof. dr Janko Cvijanović, Economics Institute, Belgrade, janko.cvijanovic@ecinst.org.rs

${ }_{2}^{2}$ Mr Barbara Rodica, School of Business and Management, Novo Mesto, Slovenia

${ }^{3}$ Prof. dr Boško Vojnović , Agricultural high School, Šabac, Serbia

${ }^{4}$ Milorad Živković, Astra plan, Brčko, Republika Srpska

${ }^{5}$ This paper forms part of the results of research on projects 179001 financed by Ministry of Education, Science Technological Development of the Republic of Serbia
} 
Cvijanović, Rodica, Vojnović, Živković: The Research on People’s Enterprise Skills...

\section{Introduction}

The term entrepreneurship includes entrepreneurial initiative but it is very difficult to distinguish clearly the typology of enterprise skills. Even though the examples in practice are different, they turn out to be mostly atypical. This explains the inability of researchers to systematize this issue.

The enterprise skills can be classified in accordance to (Maier, p. 286, 1965):

- In-born traits developed without a special training and

- Major output capabilities acquired through expertise and training.

The skills are in-born abilities acquired and evolved by training, whereas performance of the individuals comprises not only their skills, but also their ability to use the acquired skills.

Taking all these facts into consideration, it is possible to create a model of enterprise performance by taking into account elements of personal characteristics, enterprise skills as well as the elements of the business strategy and of the proper environment (industry). The skill typology developed by Katz (1974) was a basis for the model evolved by Szilagui \&.Schweiger.(1984, p.626). Three categories of the model are based on the enterprise, integrative and administrative skills.

The purpose of this article is to analyze and explore enterprise skills in Serbia by the means of survey sample. Initial parameters used in this research have been taken from Global Entrepreneurship Monitor (GEM) research related to Slovenia (GEM, 2012). Since Serbia was not covered by the GEM research, authors have conducted a pilot study that would apply to the Republic of Serbia.

\section{Methodology}

In this article we have used a survey method on the Serbian people's enterprise skills. It has been performed by the first grade agro-management students of the Agricultural high school in Šabac during their management course, in the first term of the school year 2010/11. Calculations, reports, formulas and discussions have been prepared by the authors on the basis of research results, followed by their views on certain issues. The research has covered 139 respondents from Mačva district.

These survey elements have been taken from McGraw's Guide for starting your Own Business (Harper, 1991, pp. 8-17) which has been presented by the Training Programme to Guide Entrepreneurs in the Organization. Training 
Cvijanović, Rodica, Vojnović, Živković: The Research on People’s Enterprise Skills...

programs have been developed by the Regional Agency for Small and Medium-Sized Enterprises in Kragujevac in 2004 and tested in practice in the study of people's potential enterprise performance skills at the end of 2010 and in the beginning of 2011.

The empirical part of the study shows the average results typical for the potential entrepreneurs in Serbia. The respondents circled the scores which suited the most to their characteristics on the scale 5-4-3-2-1-0-1-2-3-4-5 for each question. In accordance to the methodology, neither interviewees nor interviewers knew which side was for positive and which for negative scores. Scores were recorded on the basis of Harper's Scoring Guide, as follows:

For questions: $1,2,4,5,7,9,12,14,15$ i 17

\begin{tabular}{|l|l|l|l|l|l|l|l|l|l|l|}
\hline+5 & +4 & +3 & +2 & +1 & 0 & -1 & -2 & -3 & -4 & -5 \\
\hline
\end{tabular}

For questions: 3, 6, 8, 10, 11, 13 i 16.

\begin{tabular}{|l|l|l|l|l|l|l|l|l|l|l|}
\hline-5 & -4 & -3 & -2 & -1 & 0 & +1 & +2 & +3 & +4 & +5 \\
\hline
\end{tabular}

According to methodology the average highest possible score in empirical research is 85 , and the minimum is -85 . Table 1 shows the scores values and their corresponding features.

Table 1- Scoring guide

\begin{tabular}{|c|l|}
\hline Scores & \multicolumn{1}{|c|}{ Description } \\
\hline $50-85$ & You may be either in business or engaged in business type activity \\
\hline $20-50$ & $\begin{array}{l}\text { It is still necessary for you to work on some things, but in general, you have a } \\
\text { positive attitude towards entrepreneurship }\end{array}$ \\
\hline $0-20$ & $\begin{array}{l}\text { You may have a role in a business group but you do not take up a leadership } \\
\text { position }\end{array}$ \\
\hline 0 & Are you certain your responses have been correctly recorded? \\
\hline
\end{tabular}

Source: Harper (1981) p. 8-17

The environment attractiveness and the incentives for the legislative solutions haven't been analyzed in this article. Our study focuses on the people's enterprise skills in some parts of Serbia. 
Cvijanović, Rodica, Vojnović, Živković: The Research on People’s Enterprise Skills...

\section{Entrepreneurial activity in 2011 GEM research}

Entrepreneurial activity is in the centre of the economic and social development. In the Global Entrepreneurship Monitor (GEM) studies research on entrepreneurship skills was performed on 54 countries. The study highlights entrepreneurs' ambitions, innovations and entrepreneurship, as well as their fears and the reasons for highly trained individuals not being able to focus on their businesses (Rebernik, Tominc, Crnogaj, 2012). The GEM research for the year 2011 shows that, in spite of the recession, entrepreneurship stays the major development factor in the world. It has been estimated that about 388 million entrepreneurs were actively involved in starting and implementing their businesses in 2011. Further estimates show, for instance, that 69 million of them were either bound to become entrepreneurs with the more competitive innovative products and services which are new for customers or they will become the new ones; 18 million of them sold at least $25 \%$ of their products and services to foreign markets. Entrepreneurial activity of the adult population has been decreasing for the last three observed years, so it decreased from $4.65 \%$ to $3.65 \%$. Most entrepreneurial activity was recorded in China in 2011 $(24 \%)$, Chile $(23.75 \%)$ and Peru $(22.9 \%)$, while among the European countries Slovakia (14.2\%) Latvia and Turkey (both $11.9 \%$ ) were the leaders. In the category of the established entrepreneurs among the adult population, Slovenia was trailing with $4.8 \%$. In Europe, where the economy of most GEM countries is said to be innovative and influential, the overall entrepreneur activity was, on average, relatively low.

2011 GEM research shows that corporative entrepreneurial goals, defined as the percentage of the adult population who were going to start their own business in the next three years was, on average, higher in less developed countries, for instance Colombia $56 \%$, Chile $46 \%$, China $43 \%$. In these countries there were few open job opportunities, so greater entrepreneurship was to be expected. The smallest interest for independent entrepreneurial business career was registered in the United Arab Emirates (2\%), Japan and Russia both with $4 \%$. In Slovenia, $9 \%$ of adult population was in favor of it.

It is interesting the Slovenian respondents in 2010 research were convinced to be able to establish their own businesses because $51 \%$ of the population pointed out they had necessary abilities and skills. Slovenia scored 19th place among the 54 participating countries in that respect. As compared, only Slovakia and Poland had higher scores in Europe - Slovakia 53\% and Poland $52 \%$. Moreover, Slovenia reported below-average share of people with $31 \%$ who would have given up establishing their own businesses due to the fear of failure. As the researchers highlight (Rebernik, Širec, Tominc, 2012): "These 
Cvijanović, Rodica, Vojnović, Živković: The Research on People’s Enterprise Skills...

are encouraging results, however, further efforts should be taken in the future to provide better socio-cultural environment for entrepreneurship".

The authors of 2011 GEM research in Slovenia note that: "Belief in their own abilities does not mean much unless it leads to a greater perception of business opportunities and unless both business framework and environment are regulated and encouraging. Unfortunately, business environment has turned out to be extremely unfavorable in recent times". Comparison of business environment factors has indicated that - compared to the developed innovative economies - Slovenia lags mostly behind entrepreneurial culture, national business regulation, government programme effectiveness and entrepreneurship education. How to benefit from entrepreneurial characteristics and how to consider them as rare qualities if actually they are not evenly distributed among the people? All the above mentioned does not depend only on individuals, but also to a great extent on their direct life environment and their institutional framework within which they work.

\section{Results and discussion}

The survey containing 17 questions was conducted on the sample of 139 persons from the Mačva district in Serbia. The structure of the respondents is presented in Table 2.

Table 2 - The age and qualifications of respondents

\begin{tabular}{|l|l|l|}
\hline Scope of age & Number of respondents & $\%$ \\
\hline Up to 20 & 3 & 2 \\
\hline $21-30$ & 35 & 25 \\
\hline $31-40$ & 39 & 28 \\
\hline $41-50$ & 36 & 26 \\
\hline More than 51 & 26 & 19 \\
\hline Total & 139 & 100 \\
\hline Education & Number of respondents & $\%$ \\
\hline Primary Education & 20 & 14 \\
\hline Secondary education & 64 & 47 \\
\hline Skilled worker & 13 & 9 \\
\hline Highly skilled worker & 7 & 5 \\
\hline College degree & 17 & 12 \\
\hline Higher Education & 18 & 13 \\
\hline Total & 139 & 100 \\
\hline
\end{tabular}

Source: (Survey) 
Cvijanović, Rodica, Vojnović, Živković: The Research on People's Enterprise Skills...

The survey results are summarized and presented in Table 3.

Table 3 - Questions and answers in manual scoring

\begin{tabular}{|c|c|c|c|c|c|c|c|c|c|c|}
\hline \multicolumn{5}{|c|}{ 1. I like to work in a team } & $\begin{array}{l}\text { Has not re- } \\
\text { sponded }\end{array}$ & \multicolumn{5}{|c|}{ I like to work alone } \\
\hline+5 & +4 & +3 & +2 & +1 & 0 & -1 & -2 & -3 & -4 & -5 \\
\hline 41 & 29 & 14 & 5 & 3 & 9 & 1 & 5 & 8 & 11 & 13 \\
\hline \multicolumn{5}{|c|}{$\begin{array}{l}\text { 2. I like to work intensively for long } \\
\text { periods on what interests me }\end{array}$} & $\begin{array}{l}\text { Has not re- } \\
\text { sponded }\end{array}$ & \multicolumn{5}{|c|}{ I like to work smoothly } \\
\hline+5 & +4 & +3 & +2 & +1 & 0 & -1 & -2 & -3 & -4 & -5 \\
\hline 39 & 22 & 6 & 4 & 3 & 4 & 1 & 4 & 14 & 21 & 21 \\
\hline \multicolumn{5}{|c|}{$\begin{array}{l}\text { 3. I believe that the external factors are } \\
\text { main in deciding what will happen }\end{array}$} & $\begin{array}{l}\text { Has not re- } \\
\text { sponded }\end{array}$ & \multicolumn{5}{|c|}{ I believe I can affect things if I want to } \\
\hline-5 & -4 & -3 & -2 & -1 & 0 & +1 & +2 & +3 & +4 & +5 \\
\hline 14 & 19 & 17 & 8 & 5 & 4 & - & 6 & 10 & 33 & 23 \\
\hline \multicolumn{5}{|c|}{$\begin{array}{l}\text { 4. I like to think that what I build, I build } \\
\text { for the future }\end{array}$} & $\begin{array}{l}\text { Has not re- } \\
\text { sponded }\end{array}$ & \multicolumn{5}{|c|}{ I like to get fast results } \\
\hline+5 & +4 & +3 & +2 & +1 & 0 & -1 & -2 & -3 & -4 & -5 \\
\hline 42 & 38 & 9 & 2 & 2 & 1 & - & - & 5 & 17 & 23 \\
\hline \multicolumn{5}{|c|}{$\begin{array}{l}\text { 5. I like myself specifies the goals eve- } \\
\text { ry month, week and day }\end{array}$} & $\begin{array}{l}\text { Has not re- } \\
\text { sponded }\end{array}$ & \multicolumn{5}{|c|}{ I like to work business as it comes } \\
\hline+5 & +4 & +3 & +2 & +1 & 0 & -1 & -2 & -3 & -4 & -5 \\
\hline 30 & 18 & 10 & 6 & 3 & 3 & 1 & 3 & 11 & 27 & 27 \\
\hline \multicolumn{5}{|c|}{$\begin{array}{l}\text { 6. It is not important to measure how } \\
\text { much I advance }\end{array}$} & $\begin{array}{l}\text { Has not re- } \\
\text { sponded }\end{array}$ & \multicolumn{5}{|c|}{$\begin{array}{l}\text { I like to measure how much I advance } \\
\text { on the basis of how much I earn }\end{array}$} \\
\hline-5 & -4 & -3 & -2 & -1 & 0 & +1 & +2 & +3 & +4 & +5 \\
\hline 19 & 6 & 25 & 5 & 3 & 7 & 5 & 3 & 13 & 25 & 28 \\
\hline \multicolumn{5}{|c|}{$\begin{array}{l}\text { 7. I like to work on the problem until I } \\
\text { solved it }\end{array}$} & $\begin{array}{l}\text { Has not re- } \\
\text { sponded }\end{array}$ & \multicolumn{5}{|c|}{$\begin{array}{l}\text { I prefer to do something else than to } \\
\text { get involved in the issue even more }\end{array}$} \\
\hline+5 & +4 & +3 & +2 & +1 & 0 & -1 & -2 & -3 & -4 & -5 \\
\hline 62 & 33 & 4 & 3 & 3 & 1 & 4 & 5 & 4 & 11 & 9 \\
\hline \multicolumn{5}{|c|}{ 8. I do not accept failure } & $\begin{array}{l}\text { Has not re- } \\
\text { sponded }\end{array}$ & \multicolumn{5}{|c|}{$\begin{array}{l}\text { I agree that the failures are part of the } \\
\text { life, to learn from them }\end{array}$} \\
\hline-5 & -4 & -3 & -2 & -1 & 0 & +1 & +2 & +3 & +4 & +5 \\
\hline 20 & 9 & 9 & 8 & 3 & - & 4 & 5 & 14 & 42 & 25 \\
\hline \multicolumn{5}{|c|}{$\begin{array}{l}\text { 9. I love that all the time I know how } \\
\text { much I advance }\end{array}$} & $\begin{array}{l}\text { Has not re- } \\
\text { sponded }\end{array}$ & \multicolumn{5}{|c|}{$\begin{array}{l}\text { I prefer to work than analyze past } \\
\text { achievements }\end{array}$} \\
\hline+5 & +4 & +3 & +2 & +1 & 0 & -1 & -2 & -3 & -4 & -5 \\
\hline 31 & 18 & 5 & 3 & 2 & 5 & 2 & 1 & 12 & 33 & 22 \\
\hline \multicolumn{5}{|c|}{$\begin{array}{l}\text { 10. I prefer others to take the lead } \\
\text { responsibility for the success or failure }\end{array}$} & $\begin{array}{l}\text { Has not re- } \\
\text { sponded }\end{array}$ & \multicolumn{5}{|c|}{$\begin{array}{l}\text { I love to take personal responsibility for } \\
\text { the success / failure }\end{array}$} \\
\hline-5 & -4 & -3 & -2 & -1 & 0 & +1 & +2 & +3 & +4 & +5 \\
\hline 7 & 7 & 8 & 7 & 7 & 2 & 3 & 3 & 23 & 37 & 35 \\
\hline \multicolumn{5}{|c|}{$\begin{array}{l}\text { 11. I prefer not to discuss my business } \\
\text { with people from by }\end{array}$} & $\begin{array}{l}\text { Has not re- } \\
\text { sponded }\end{array}$ & \multicolumn{5}{|c|}{$\begin{array}{c}\text { I like to seek advice of expert, to listen } \\
\text { carefully }\end{array}$} \\
\hline-5 & -4 & -3 & -2 & -1 & 0 & +1 & +2 & +3 & +4 & +5 \\
\hline 23 & 11 & 12 & 2 & 3 & 1 & 3 & 4 & 8 & 35 & 37 \\
\hline \multicolumn{5}{|c|}{$\begin{array}{l}\text { 12. I always myself ask the standards } \\
\text { and raise them to achieve their goal }\end{array}$} & $\begin{array}{l}\text { Has not re- } \\
\text { sponded }\end{array}$ & \multicolumn{5}{|c|}{$\begin{array}{c}\text { I like that others set standards and } \\
\text { develop business }\end{array}$} \\
\hline+5 & +4 & +3 & +2 & +1 & 0 & -1 & -2 & -3 & -4 & -5 \\
\hline 36 & 41 & 18 & 5 & 3 & 5 & 6 & 6 & 7 & 7 & 5 \\
\hline
\end{tabular}


Cvijanović, Rodica, Vojnović, Živković: The Research on People’s Enterprise Skills...

\begin{tabular}{|c|c|c|c|c|c|c|c|c|c|c|}
\hline \multicolumn{5}{|c|}{$\begin{array}{l}\text { 13. I really need to be sure of the fu- } \\
\text { ture }\end{array}$} & $\begin{array}{l}\text { Has not re- } \\
\text { sponded }\end{array}$ & \multicolumn{5}{|c|}{$\begin{array}{l}\text { I can not deal with the uncertainty } \\
\text { regarding the essentials }\end{array}$} \\
\hline-5 & -4 & -3 & -2 & -1 & 0 & +1 & +2 & +3 & +4 & +5 \\
\hline 43 & 26 & 11 & 1 & 2 & 2 & 2 & 8 & 18 & 14 & 12 \\
\hline \multicolumn{5}{|c|}{$\begin{array}{l}\text { 14. I like to be totally dedicated to what } \\
\text { I do }\end{array}$} & $\begin{array}{l}\text { Has not re- } \\
\text { sponded }\end{array}$ & \multicolumn{5}{|c|}{$\begin{array}{l}\text { More suits me to live without too obli- } \\
\text { gations }\end{array}$} \\
\hline+5 & +4 & +3 & +2 & +1 & 0 & -1 & -2 & -3 & -4 & -5 \\
\hline 46 & 38 & 15 & 3 & 2 & 1 & 2 & 4 & 8 & 9 & 11 \\
\hline \multicolumn{5}{|c|}{$\begin{array}{l}\text { 15. I love to people think that I do what } \\
\text { I say I will do }\end{array}$} & $\begin{array}{l}\text { Has not re- } \\
\text { sponded }\end{array}$ & \multicolumn{5}{|c|}{$\begin{array}{c}\text { It is not always possible to keep the } \\
\text { promise, unforeseen events can } \\
\text { change priorities }\end{array}$} \\
\hline+5 & +4 & +3 & +2 & +1 & 0 & -1 & -2 & -3 & -4 & -5 \\
\hline 51 & 23 & 9 & 2 & 3 & 2 & - & 7 & 12 & 20 & 10 \\
\hline \multicolumn{6}{|c|}{\begin{tabular}{|l|c|} 
16. I like to 'play' it safe & $\begin{array}{c}\text { Has not re- } \\
\text { sponded }\end{array}$ \\
\end{tabular}} & \multicolumn{5}{|c|}{ I like to take chances } \\
\hline-5 & -4 & -3 & -2 & -1 & 0 & +1 & +2 & +3 & +4 & +5 \\
\hline 50 & 29 & 10 & 3 & 2 & 2 & 4 & 8 & 9 & 10 & 12 \\
\hline \multicolumn{5}{|c|}{$\begin{array}{l}\text { 17. I like to take into account the 'pros } \\
\text { and cons' of a risk before it is take }\end{array}$} & $\begin{array}{l}\text { Has not re- } \\
\text { sponded }\end{array}$ & \multicolumn{5}{|c|}{ I love to gamble } \\
\hline+5 & +4 & +3 & +2 & +1 & 0 & -1 & -2 & -3 & -4 & -5 \\
\hline 39 & 36 & 16 & 8 & 4 & 1 & 6 & 7 & 5 & 8 & 9 \\
\hline
\end{tabular}

Calculation of the average values was made by using the following formula:

$S=\{(x 5+x 4+x 3+x 2+x 1)-(y 1+y 2+y 3+y 4+y 5)\} / b i$

where the following represent:

$X$ number of respondents with the score $+5 /-5$

$\mathrm{bi}=$ number of respondents

Table 4 and 5 show the number and total scores from the survey.

Table 4 - Number of responses according to respondents' scores

\begin{tabular}{|c|c|c|c|c|c|c|c|c|c|c|}
\hline & \multicolumn{4}{|c|}{ Answers with positive scores } & \multicolumn{4}{c|}{ Answers with negative scores } \\
\hline Scores & 5 & 4 & 3 & 2 & 1 & -1 & -2 & -3 & -4 & -5 \\
\hline 1. & 41 & 29 & 14 & 5 & 3 & 1 & 5 & 8 & 11 & 13 \\
\hline 2. & 39 & 22 & 6 & 4 & 3 & 1 & 4 & 14 & 21 & 21 \\
\hline 3. & 23 & 33 & 10 & 6 & 0 & 5 & 8 & 17 & 19 & 14 \\
\hline 4. & 42 & 38 & 9 & 2 & 2 & 0 & 0 & 5 & 17 & 23 \\
\hline 5. & 30 & 18 & 10 & 6 & 3 & 1 & 3 & 11 & 27 & 27 \\
\hline 6. & 28 & 25 & 13 & 3 & 5 & 3 & 5 & 25 & 6 & 19 \\
\hline 7. & 62 & 33 & 4 & 3 & 3 & 4 & 5 & 4 & 11 & 9 \\
\hline 8. & 25 & 42 & 14 & 5 & 4 & 3 & 8 & 9 & 9 & 20 \\
\hline 9. & 31 & 18 & 5 & 3 & 2 & 2 & 1 & 12 & 33 & 22 \\
\hline 10. & 35 & 37 & 23 & 3 & 3 & 7 & 7 & 8 & 7 & 7 \\
\hline 11. & 37 & 35 & 8 & 4 & 3 & 3 & 2 & 12 & 11 & 23 \\
\hline 12. & 36 & 41 & 18 & 5 & 3 & 6 & 6 & 7 & 7 & 5 \\
\hline
\end{tabular}


Cvijanović, Rodica, Vojnović, Živković: The Research on People’s Enterprise Skills...

\begin{tabular}{|c|c|c|c|c|c|c|c|c|c|c|}
\hline 13. & 12 & 14 & 18 & 8 & 2 & 2 & 1 & 11 & 26 & 43 \\
\hline 14. & 46 & 38 & 15 & 3 & 2 & 2 & 4 & 8 & 9 & 11 \\
\hline 15. & 51 & 23 & 9 & 2 & 3 & 0 & 7 & 12 & 20 & 10 \\
\hline 16. & 12 & 10 & 9 & 8 & 4 & 2 & 3 & 10 & 29 & 50 \\
\hline 17. & 39 & 36 & 16 & 8 & 4 & 6 & 7 & 5 & 8 & 9 \\
\hline Sum & 589 & 492 & 201 & 78 & 49 & 48 & 76 & 178 & 271 & 326 \\
\hline
\end{tabular}

Table 5 - The overview of responses and scores

\begin{tabular}{|c|c|c|c|c|c|c|c|c|c|c|}
\hline \multicolumn{8}{|c|}{} & \multicolumn{7}{|c|}{ The sum of positive scores on the ques- } & \multicolumn{5}{c|}{ The sum of negative scores on the ques- } \\
\hline Scores & 5 & 4 & 3 & 2 & 1 & -1 & -2 & -3 & -4 & -5 \\
\hline 1. & 205 & 116 & 42 & 10 & 3 & 1 & 10 & 24 & 44 & 65 \\
\hline 2. & 195 & 88 & 18 & 8 & 3 & 1 & 8 & 42 & 84 & 105 \\
\hline 3. & 115 & 132 & 30 & 12 & 0 & 5 & 16 & 51 & 76 & 70 \\
\hline 4. & 210 & 152 & 27 & 4 & 2 & 0 & 0 & 15 & 68 & 115 \\
\hline 5. & 150 & 72 & 30 & 12 & 3 & 1 & 6 & 33 & 108 & 135 \\
\hline 6. & 140 & 100 & 39 & 6 & 5 & 3 & 10 & 75 & 24 & 95 \\
\hline 7. & 310 & 132 & 12 & 6 & 3 & 4 & 10 & 12 & 44 & 45 \\
\hline 8. & 125 & 168 & 42 & 10 & 4 & 3 & 16 & 27 & 36 & 100 \\
\hline 9. & 155 & 72 & 15 & 6 & 2 & 2 & 2 & 36 & 132 & 110 \\
\hline 10. & 175 & 148 & 69 & 6 & 3 & 7 & 14 & 24 & 28 & 35 \\
\hline 11. & 185 & 140 & 24 & 8 & 3 & 3 & 4 & 36 & 44 & 115 \\
\hline 12. & 180 & 164 & 54 & 10 & 3 & 6 & 12 & 21 & 28 & 25 \\
\hline 13. & 60 & 56 & 54 & 16 & 2 & 2 & 2 & 33 & 104 & 215 \\
\hline 14. & 230 & 152 & 45 & 6 & 2 & 2 & 8 & 24 & 36 & 55 \\
\hline 15. & 255 & 92 & 27 & 4 & 3 & 0 & 14 & 36 & 80 & 50 \\
\hline 16. & 60 & 40 & 27 & 16 & 4 & 2 & 6 & 30 & 116 & 250 \\
\hline 17. & 195 & 144 & 48 & 16 & 4 & 6 & 14 & 15 & 32 & 45 \\
\hline Sum & 2945 & 1968 & 603 & 156 & 49 & 48 & 148 & 534 & 1084 & 1630 \\
\hline & $\mathrm{X} 5$ & $\mathrm{X} 4$ & $\mathrm{X} 3$ & $\mathrm{X} 2$ & $\mathrm{X} 1$ & $\mathrm{Y} 1$ & $\mathrm{Y} 2$ & $\mathrm{Y} 3$ & $\mathrm{Y} 4$ & $\mathrm{Y} 5$ \\
\hline
\end{tabular}

Therefore using the formula (1) we get:

$\{(x 5+x 4+x 3+x 2+x 1)-(y 1+y 2+y 3+y 4+y 5)\} / b i=$

$\{(2945+1968+603+156+49)-(48+148+534+1084+1630)\} / 139=$

$\{(5721-3444)\} / 139=2277 / 139=16.4$

The average score recorded in our survey is 16.4

The results tell us that the average potential entrepreneurs in Serbia like working in the group, where 41 respondents performed the highest score - (score 5). Such results can be considered satisfactory. The research showed that 
they liked working intensively over a longer period of time but only if they did a job they were really interested in. Some 42 respondents performed the highest scores by stating: "If they want they can also influence the course of upcoming events to build their future". They would perform business as it came without setting long-term goals every day. In these statements the potential entrepreneurs performed the highest scores in several scorings, yet more points have been scored for the possibilities they would do the job when it came. Measuring and promotion can be considered suitable for them only if they earned money. Problems are dealt with as problems until they are finally solved. In responding to this issue, 62 individuals performed the highest scores (score 5). 33 of them performed the score 4 . The majority of them accept that failures are actually part of life so they can learn from them. This can be considered as their major characteristic. Potential entrepreneurs do not control their evolvement enough because, from their standpoints, they prefer working to analyzing past achievements. This can be considered problematic and can lead to failure when the company's activities should be implemented. Our potential entrepreneurs were ready to take their personal responsibility for their problems and to take all benefits for the final success. In this respect, 72 respondents performed the highest score. Also, 72 of them scored they would ask for advice experts for the things they didn't know. Potential entrepreneurs recognize the need of high standards in business so they are ready to raise them to a higher level - after having taken the former steps. 109 respondents, who scored all scores in the range of 1 to 5 , were in favor of this. 85 individuals responded negatively to the issue 13 on district safety because they meant they had to be certain about the future. This characteristic is not desirable while doing business because the major and important things are believed to be performed providing that the potential entrepreneurs are able to face the uncertainty about the future. Apart from this, they prefer focusing on their work. 105 respondents were in favor of this characteristic, only few of them would live without any excessive responsibility.

Analogically, a very large number of our entrepreneurs would like to "bet" on their certainty in future. It's good that they are convinced they need to take into account "pros and cons" for taking risks before taking the necessary measures. According to the research results, the potential entrepreneurs are aged 21 to $30-(28 \%$ of all respondents). The next group's research results show they are a bit older - from 41 to 50 or $26 \%$ of all respondents. However, this group is almost identical to the earlier youngest group aged 21 to 30 . This result seems logical because the rate of unemployment is the lowest among the people aged 30 to 40 . The other age groups' results show that the unemployment problem exists more in their opinions.

The group of secondary school graduates is the most interested in starting their own business. It also seems logical - as National Employment Office in 
Cvijanović, Rodica, Vojnović, Živković: The Research on People’s Enterprise Skills...

the Republic of Slovenia reports - that the majority of secondary school graduates are unemployed. Moreover, the typical results show that more than $20 \%$ of the potential entrepreneurs have finished primary school, however, more than $18 \%$ of them are college and university graduates as well. So, the unemployment problem actually exists in each educational structure.

Finally, the research results in Harper's manual for scoring in Starting your own Business in Serbia shows an average score of 16.4 out of maximum 85. The descriptive mark according to Table 1 for this score is as follows: The potential entrepreneurs may play a role in their business group, but they do not take up an initiative for the leadership position.

\section{Conclusions}

The research based on GEM methodology which was conducted in the Serbian region of Mačva shows that entrepreneurs have only modest enterprise skills. Such results were expected, due to the fact that entrepreneurship as a concept in this region is only in the early stages. The results show that potential entrepreneurs in Mačva need additional training. The results also show that, on average, they graduated from secondary school and that they differ in age. In accordance with Harper's manual score, respondents from Serbia scored 16.4 on average, which places it below average compared to countries that participated in 2011 GEM survey.

\section{References}

GEM - Global enterpreneurship monitor 2011, extended report (2012) Retrieved from http://www.gemconsortium.org/docs/download/2200

Harper, S.C. (1991). The Mcgraw- Hill Guide to Starting Yuor Own Business. (pp. 817). New York: McGraw-Hill Inc.

Katz, R.L. (1974). Skills of an effective administrator. Harvard Business Review, 52(5), 90-102.

Rebernik, M., Širec, K., \& Tominc, P. (2012). Razvojni potenciali slovenskega podjetništva: Slovenski podjetniški observatorij 2011/12. (p. 112). Maribor: Ekonomsko-poslovna fakulteta.

Rebernik, M., Tominc, P., \& Crnogaj, K. (2012). Usihanje podjetništva v Sloveniji: GEM Slovenija 2011. (p. 133). Maribor: Ekonomsko-poslovna fakulteta.

Szilagui, A.D., \& Schweiger, D.M. (1984). Matching managers to strategie. Academy of Management Review, 9(4), 626-637 